\title{
History, Memory and Fiction: What Boundaries?
}

\section{Sérgio Campos Matos}

sergiocamposmatos@gmail.com

Associate Professor with Aggregation

Universidade de Lisboa

Alameda da Universidade

1600-214 - Lisbon

Portugal

\begin{abstract}
$20^{\text {th }}$ century sociologists and historians established a clear distinction between history and memory. But in the last decades our attention has been called to what exists in common between these two fields that do not always coincide. In this article, I intend to problematize the complex relationship between history and memory: the critical demands of history writing and the register of the various memories (individual memory, collective memory), also equating the relationship between memory and -forgetfulness. And what about history? What distinguishes it from fiction? To what extent are memories permeable to imagination? We all fictionalize our past. Could we reduce the writing of history to a narrative dimension?
\end{abstract}

Keywords

History; Memory; Fiction. 


\section{History and Memory}

In the last decades the concept of memory has proliferated extraordinarily. It became trivialized and even turned into a crutch in scientific language and in ordinary speech. How to explain trivialization (but also revaluation) of memory that goes back to the 70 s and 80 s? It was around that time that evident signs of crisis emerged in the bipolar international system. It was a crisis (1973) and expansion of capitalism on a global scale, but also of what was called state socialism in Eastern Europe and the USSR.

Meanwhile, in the western world a neo-liberal theory was stated that spread the much purported conviction, according to which the market self-regulates, dismissing the restraining state intervention and sacrificing solidarity and social justice. Globalization gained new technological outlines - the era of affordable computing for the masses - and profoundly changed the experience of people. The notions of time and space have become deeply altered. Migration and immigration movements increased; the phenomena of uprooting and dissolution of ties grew in traditional societies. New memory supports have become common but have revealed their capacity of being a menace to the memory of minority human groups - such as rural communities that have become unpopulated. Koselleck alluded to the unprecedented acceleration of the modernity experience, acceleration of time, rupture with the past, rupture with the field of experience, with deep effects in the political and social vocabulary at the end of the $18^{\text {th }}$ and beginning of the $19^{\text {th }}$ centuries (KOSELLECK 1990). Keep in mind, moreover, that Karl Jaspers, a few decades ago, had already considered a new kind of historical consciousness from the time of the liberal revolutions: since the French Revolution, modern man began viewing his time as opposed to other times, generalizing the feeling of rupture with earlier times (JASPERS 1953 , p. 10-24).

The narrowing of the idea of future and, specially, of the teleological narratives of history, is expressed into a reflux on the present - presentism (HARTOG 2003). The world threats - financial crisis, pollution, global warming, famines, epidemics, drug dealing - and the apocalyptic mentality associated to them, contribute decisively for this centralism of the present. Even for this same reason, the knowledge of the past continues to be indispensable to question the complexity and difficulty of understanding our time. And perhaps, never as much as today the search of historical memory, of collective and individual memories, is so evident. We live a vertiginous time at the rhythm of technological innovation and excess of instantaneous information that began spreading by the end of the $20^{\text {th }}$ Century. It is true that the awareness of time acceleration is much lower and has remained well documented in the artistic experimentalism of modern vanguard, from cubism and futurism, at the beginning of this troubled century. But nowadays, when in Eastern Europe the peasants are gone and the rural world became empty, the feeling and the consciousness of that acceleration are much more generalized.

It is true that the places of memory and the rituals of memory have multiplied as never before - everything becomes patrimony, from natural places 
to the old dead factories, from the ruins and their illusion of eternity to the experimentalism of artistic installations, without forgetting the multiplication of museums, monuments, memorials, archives - everything is commemorated. Memory has become an object of mass consumption. But it is also not less obvious that the non places referred to by Marc Augé have invaded our lives motorways, apart-hotels, airports, hospitals and clinics that resemble offices, universities that resemble hospitals, restaurants reminiscent of offices. And the places of trauma - battle fields, prisons, concentration camps - are the object of renewed attention. Trauma translates itself as a break in memory (LACAPRA 2008 , p. 22), producing amnesia, difficulty in verbalizing experience. What also entangles a break This also implies a break in the representations of a past that does not pass and does not cease to re-enroll in the present, "it returns the memory and the recounting, repetitive and incessant, of the dead" (SANFELIPPO 2013, p. 29).

In all this we can perceive one of the paradoxes of our time, divided between the almost obsessive culture of memory and, on the other hand, an accelerated culture of forgetfulness - the accelerated amnesia. Tony Judt already noticed this contrast at the beginning of the new millennia (JUDT 2009; 2010). And the philosopher Jose Gil applied to the Portuguese case the concept of "non-inscription", this is the immediate forgetting of what happens in the present (GIL 2005, p. 15-18). Perhaps never as today the dead are forgotten and death is withdrawn from the frenzy of life. But the past always erupts in the present. As stated by Auguste Comte, the dead govern the living.

Hence, it can be asked, how do history and memory relate? What differences are there between the registries of history proper and the registries of memory? It is, after all, a question of limits. Michel de Certeau considered this problem of limits - that is to say: the differentiation, the alterity, the relation with other discourses - central to historical science (CERTEAU 1975, p. 64-69). In the $20^{\text {th }}$ Century French sociology, from Durkheim to Maurice Halbawchs, the difference between history and memory was stressed. Maurice Halbawchs established a clear distinction between collective memories and historical memory. Collective memories would cover, in a very broad sense, what is left of the past in the experience lived by human communities, urban or rural communities, ethnic groups, professions, etc. Historical memory would be the product of a histographical tradition constructed by historians, out of lived time (but would it be this way really?). Pierre Nora accepted this distinction (NORA 1978), characterizing collective memory as "globalizing and without boundaries", "fluid" but divided. On one hand, historical memory would be "analytical and critical", "precise and different", relieving us from the exercise of reason and unifying. Nonetheless, Nora warned that, during a long time, history and memory had more or less become confused, constituting that "tradition of memory" (NORA 1984, p. XXII). On the other hand, Jacques Le Goff was able to distinguish, in very definitive and watertight terms, two histories: the one belonging to collective memory ("essentially mythical, deformed, anachronic", constituting "the lived") and that of the historians, where this latter history should "clarify" 
and "rectify" the former (LE GOFF 1984, p. 166). He recognized, however, that history became much more exposed to the pressure of collective memories (LE GOFF 1984, p. 44): it is the case of life experiences in dictatorial regimes or, of the Holocaust.

As a matter of fact, since the 1980's, and in particular in the papers gathered in The invention of tradition (HOBSBAWM; RANGER 1983) and in Les lieux de la memoire (NORA 1984), multiple forms of expression of memory became the object of historians attention - of course, we could go back to the works of Aby Warburg, of Maurice Halbawchs, and of Frances Yates, who have not had an immediate impact, comparable to those works of the 80's yet. Also the history of history was cultivated as never before. And this movement contributed to reposition, the relationship between history and memory.

One could phrase the question from the differences and similarities between the two terms. Patrick Lacapra formulated the problem well: "memory is simultaneously, more or less what history is and vice-versa. History might not ever capture some elements of memory: the feeling of an experience, the intensity of happiness or of suffering" (LACAPRA 2008, p. 34). As we shall see, liberal and romantic historians were already aware of this difference - the novelist is able to capture what the historian is hardly able to do: the feeling, the imagination. On its side, history tests the memory, insofar as it constitutes a critical discourse that is based on requirements of documentary evidence and heuristic and hermeneutic rigor. It involves a relationship with alterity but it is also an exercise in taking distance in relation to the objects of study, in relation to each other. Does this mean it cannot involve empathy with the object? Certainly not. But within the limits of a certain caution and critical vigilance. If enthusiasm and even passion in the study of the past can favor the historian and the quality of his work, truth be said that, if the feelings are not controlled, he might fall into the practice of the courthouse history (in the famous words of Lucien Febvre), who feeds on value judgments decrying or, rather, weaving apologies. There are well known cases in which the feeling of patriotic loyalty deformed the reading of the past of nations and compromised historical rigueur.

Keeping a distance, the same is valid for poetic creation. The live expression of feeling, not mediatized by an intense intellectual and formal work, can compromise artistic quality. As Ruy Belo stated in one of his poems, "I do not usually as a rule say what I feel / but I take advantage of what I feel to say anything" (BELO 1980, p. 161). And Portuguese poets such as Fernando Pessoa, Jorge de Sena or António Gedeão, did they not call attention to the relevance of intellectual work in literary creation? In 1932, Pessoa criticized the Portuguese writers and artists for limiting themselves to voice simple emotions "without the aid of intelligence or culture". He criticized them for their absence of "coordination for intellectual will of the elements supplied by emotion" (PESSOA [1946], p. 152).

Memory prolongs the past in the present but, as opposed to history, it is affective and magical" (TRAVERSO 2005, p. 28). It is next to experience lived - in this sense it is always partial, linked to the data of feelings, to imagination 
and even to dreams (POMIAN 2007, p. 176). As the great Spanish film-maker Luis Buñuel admitted in the remarkable memoir he dictated to his friend JeanClaude Carrière: "Memory is permanently invaded by the imagination and dreams" (BUÑUEL 1983, p. 9). Buñuel added:

If I was told: you have twenty years of life left, what do you want to do with the twenty four hours of each of those days you are going to live? He answered: give me two hours of active life and twenty two hours of dreams, with the condition I can remember them - because dreams only exist through memory, that caresses them (BUÑUEL 1983, p. 100).

And he refers to, as an example, one of the recurring dreams he had throughout his life, that of his return to his childhood house in Calanda (Aragon), where the apparition of his father's ghost, the night of his wake, after his death, repeated itself.

Individual memories - and collective memories - are always selective. We have all had that banal experience: we remember episodes we shared with friends or family which they have forgotten. Or vice-versa: they remember things we have forgotten. History is also selective - it is the result of choices, conscious or unconscious. We choose a subject, a question, a point of view - a view from a certain point. Why do we become interested in a certain subject and not in another? As Pomian recalls, history is selective in a different way to that of memory and selective in a controlled way: the historian chooses the problem, the method to which he will appeal (POMIAN 2007, p. 214). But the historian works with memories - transmitted orally, in writing, manifest or latent in the various vestiges left by men and women of the past. In this sense, he is a debtor to memory. On the other hand, he should not forget that those memories are sources, documents, that to effectively be so, need to be submitted to a critical questionnaire. As the Portuguese historian Vitorino Magalhães Godinho recalled, they are only sources if they are built and worked on by the historian (GODINHO 2009). This involves making an effort that involves critical distancing, decentring.

More recently, Fernando Catroga has highlighted the closer relationship between retrospective memory and retrospective historiography. In his view there are characteristics of memory that are also present in histographical work: finalism, presentism, verisimilitude and representation. And resuming the reflections of Michel de Certeau, who approaches the writing of history to the cult of the dead - history as a "gesture of burial", comparable to the domestication of the dead and the language of cemeteries (CATROGA 2011, p. 34). It is a fact that both, history as memory, deal with absence, refer to absent objects. In both there are silences and repressions. But the work of the historian has cognitive and authenticity demands, limits that, obviously, are not present in the working of memory. Not being incompatible, memory and history however, live a creative tension relationship. Still, I do not believe, as Gerard Noiriel, that all written disclosures fall within the category of memory writings (NOIRIEL 2005 , p. 340) - there is a vulgarization produced by experts who maintain the requirements of historical criticism. 
On the other hand, based on Paul Ricoeur, Roger Chartier systematized the differences between history and memory: 1) the distinction between testimony and document; 2) the difference between the immediate character of reminiscence and the construction character of historical explanation; 3) the distance between the fidelity (or not) of memory and the truthful intention of history (CHARTIER 2009, p. 353-355), that has been underlined by so many historians.

As it has been suggested, memory is often commanded by affection and unexpected associations. The plain recollection - Aristoteles' mneme - is in every case very different from anamnésis (rappel, remémoration), active search that is the result of a voluntary effort. Memories can be more permeable to imagination. As Paul Ricoeur noted, there is a memory that imagines, linked to dreams, as an abstraction of the present action, linked to the useless (RICOEUR 2000). We could give numerous examples of autobiographical texts of great writers and even historians who, in some way, idealized or reinvented their past. The enigma of the presence of the absent, as the French philosopher noticed, is something in common to imagination and to memory (RICOEUR 2000, p. 3). As a matter of fact, memory still is, to a large extent, a mystery. As the talent of artists is a mystery.

\section{Memory and Fiction}

It is here that it is interesting to establish a relationship between memory and fiction. A Portuguese novelist of the $20^{\text {th }}$ Century, Vergílio Ferreira, suggested that somebody's longings are our longings. In this way, he underlined the intimate relationship between the self and the others in the actual construction of individual identity and memory. Between the individual memory and the collective memory there is an intermediate level where affections have great relevance, in which a relationship is established between the memories lived by individuals and the public memory of communities - the level of the relationship with those near us, with those who approve of us (RICOEUR 2000, p. 161).

A key question can be formulated: how to represent the past - that is to say, the absent? What can there be in common, in this respect, the records of history, of literature, of memory? History, memory and fiction represent absences in different ways.

In this sense, much earlier than the so called linguistic turn, romantic historians made very interesting contributions. And, nonetheless, they are many times forgotten. Let us take three examples. One of them is of the Englishman Macaulay, one of the harbingers of what would become known by the wigh paradigm - the model of liberal historiography in Great Britain. In 1828, Macaulay wrote a theoretical text about history writing, in which he raises a central problem: should the way of reconstituting the past that the historian adopts resemble the romance mode? If the author of the History of England (1848-1855) showed himself very critical in relation to rationalist philosophies of the $18^{\text {th }}$ Century history, he did not stop outlining the "imaginary" concept of a history attentive to detail, to the singular but also to the collective, the part and the whole: 
The perfect historian is he in whose work the character and spirit of an age is exhibited in miniature. He relates no fact, he attributes no expression to his character, which is not authenticated by sufficient testimony. But by judicious selection, rejection, and arrangement, he gives to truth those attractions which have been usurped by fiction. In his narrative a due subordination is observed; some transactions are prominent, others retire. But the scale on which he represents them is increased or diminished, not according to the dignity of the persons concerned in them, but according to the degree in which they elucidate the condition of society and the nature of man. He shows us the court, the camp, and the senate. But he shows us also the nation. He considers no anecdote, no peculiarity of manner, no familiar saying, as too insignificant for his notice, which is not too insignificant to illustrate the operation of laws, of religion, and of education, and to mark the progress of the human mind. Men will not merely be described, but will be made intimately known to us. The changes of manners will be indicated, not merely by a few general phrases, or a few extracts from statistical documents, but by appropriate images presented in every line (MACAULAY 1828, p. 4).

We can approximate this concept to that of Jules Michelet's history of intention: "full resurrection of life" of men of the past: "More complicated still, more frightening was my problem, placed as "full resurrection of life", not on its surfaces but in its deep organisms and interiors. No wise man would have imagined it. Fortunately I had not" (MICHELET 1981, p. 16). ${ }^{1}$

On his side, Herculano compared history to a "polygonal marble column" that the historian must contemplate from various angles.

History can be compared to a polygonal marble column. Whoever wishes to examine it, must walk around it, contemplate all its faces. What has been done among us, with honorable exceptions, is to look one way, count the grain of the stone, and measure its height in hand-spans, inches and lines (HERCULANO 1842, p. 220).

But in 1840, before embarking on the production of his History of Portugal (1846-53), Herculano recognized that, under certain conditions, a novelist "could be more veridical than the historian" in his approach to the past since he would be more conversant than the historian in establishing a parallelism between feelings and the "genius of the people". What conditions were these? In his view, when the available sources allowed knowing the national and individual character, to know "the intimate story of men who are no longer" the novel could scrutinize better than history. There were good examples, Herculano noted: Walter Scott, Victor Hugo, Alfred de Vigny (note that this last author had a good notion that history did not penetrate in the intimacy of what is human). And he stated, convinced that, in this respect, the novel "tells more truths than a good half-dozen good historians" (HERCULANO 1840, p. 243-244). In any case, in Macaulay, as well as in Michelet or in Herculano, there is the intention of achieving a totalizing history that represents life as a whole - without forgetting its intimate dimension.

\footnotetext{
${ }^{1}$ In the original: "Plus compliqué encore, plus effrayant était mon problème posé comme réssurection de la vie intégrale, non pas dans ses surfaces, mais dans ses organismes intérieurs et profonds. Nul homme sage n'y eût songé. Par bonheur, je ne l'était pas".
} 
How to understand Herculano's position, he who, a few years later, with his History of Portugal, contributed as no-one to legitimate history as an autonomous scientific discipline in his country? In the first place it should be remembered that the greatest Portuguese historian of the $19^{\text {th }}$ Century began his career as a historical journalist and novelist. In fact, with two great concerns: to broaden popular education and knowledge of the national past. In his concept of historical novel there already was the notion of veracity - the real depth of the facts presented as literature. Or rather verisimilitude. To the intentionality of experience and of verisimilitude, he added the worry of authenticity. ${ }^{2}$ In the second place, the public reactions raised by the publication of the first volume of his History of Portugal, mainly from the conservative clergy, very much centered in the omission of the providential tradition of the miracle of Ourique as the moment of the foundation of independence and also the myth of the identity between Portuguese and Lucitanians, led the author to develop a systematic criticism towards "fabulous history" - that is to say, a mythical history that did not differentiate myth and history -, contributing in this way decisively to the empowerment of history in relation to literature.

The historical novel that was generalized in the first half of the $19^{\text {th }}$ Century has the intention of representing and making the past be relived, inventorying human actions, characterizing characters, describing environments. Not an easy task, above all when the times which were sought to be revived were so distant and so diverse - the Middle Ages. But with novelists as Balzac or Stendhal, the novel became contemporary, addressed the present or the near past, in a wide observation field, in which horizons multiplied.

In the case of Le rouge et le noir (1830), Stendhal was inspired by and drew upon true facts reported - the Berthet trial - giving the work a significant sub-title: "Chronicle of 1830". It is sensitive to his concern of drawing a picture of society and the political habits of his time. Not by chance, the action takes place in three stages: a small provincial town in France (Verrières), a middle sized city (Besançon) and the capital city of the country - Paris. Although it is evident that the novelistic representation leads the Author to dive in the complex psychology of his characters and their behaviors - above all in the cases of Julien Sorel or of Mme de Rênal -, it is also true that there is in Stendhal an intention of representation of the real, that he theorizes himself:

A novel is a mirror that walks on a big road. Now it reflects to our eyes the blue of the heavens, now the mud bogs of the road. And the man who carries the mirror in his basket will be accused by you of being immortal. His mirror shows the mud, and you accuse the mirror (STENDHAL 1991, p. 254). ${ }^{3}$

\footnotetext{
2 "Keep in mind very clearly, the distinction, that goes back to antiquity, between what is "real" - on the side of history - and what is "likely" - which refers to the 'order of narrative' - (of imitation or 'poetry')" (BARTHES 1987 , p. 135-136)

${ }^{3}$ In the original: "...un roman est un miroir qui se promene sur une grande route. Tantot il reflète a nos yeux l'azur des cieux, tantot la fange des bourbiers de la route. Et l'homme qui porte le miroir dans sa hotte sera par vous accusé d'être immoral. Son miroir montre la fange, et vous accusez le miroir".
} 
Julien Sorel, the son of a carpenter, excluded from high society, tutor of an aristocratic family, lives clandestinely his love for his lady employer and his admiration for Napoleon in the conservative France of the Restoration. He is a hero and an anti-hero. His path is tortuous, between love and the ambition of social climbing and power. Truth and fiction are indissolubly linked. And through his entering in the subjectivity of his characters, Stendhal represents the real. Napoleon, Julien's secret myth embodies, after all, that all dreams are possible.

In this way, we understand the capacity a great novelist has, of representing the absent in a more credible way than a historian would be able to. The attention to "details, uncertainties, the aleatory" (HARTOG 2013, p. 178), contribute decisively to this effect. As Roland Barthes perceived, with modernity a new verisimilitude emerged that was realism, in the sense that "all discourse that accepts enunciation credited only by the referent". It is true that history is endowed with the intention of capturing the "real" in an objective way - alongside other authentication tools such as photography, exhibitions of antiques or worship of places of memory - preceded realism in literature (BARTHES 1987, p. 136). But how could (and can) the historian "penetrate the intimate history of men who are no more" to which Herculano referred to, when there are no documents to sustain him? If the behavior of our contemporaries, who we live with, surprises us every day, for good or for bad, if the communication between friends and lovers is anything but linear and transparent ${ }^{4}$, how can we admit that the psychology of "men who are no more" become directly accessible to the historian? In fact, the psychological profile of someone who lived in the past is irreducible, he will only be able to offer himself to the historian in a mediate way, built through the testimonies he left or through coeval testimonies. And even so, insurmountable difficulties remain. What led the novelist António Lobo Antunes, in a recent chronicle, to ask himself if "the only possible biography of an artist would not be that of his work, page by page, chapter by chapter? It is the way of knowing the biographee, study his work because, after all, it is the only place the person is in". And, even though, to write a real biography, concluded Lobo Antunes, metaphorically, "only leaving many blank pages. All pages blank" (ANTUNES 2012, p. 13).

It may be asked: and self-biographies and memoirs? They can be of major interest, no doubt. For all what is in them - and also for what is not in them, that is. For the silences and forgetfulness. An example: in the recent and notable posthumous book by the Portuguese poet António Gedeão, alias Rómulo de Carvalho (1906-1997) (CARVALHO 2010) - an excellent source for an approximation to the way how people lived in a middle-class environment in Lisbon in the 20 s and 30 s - the absence of references to international occurrences that marked the time lived by the author: the Spanish Civil War, the Second World War, is surprising. On the other hand, there are many detailed pages dedicated to the family, to the surprising experiences of a middle-class family,

${ }^{4}$ For Niklas Luhmann (1999) it is really impossible to access the total knowledge of another person in all its fullness. 
the relationship between the author and his peers, between the author and the editors. In this field it is a very revealing book of small miseries but also of human greatness. Yet, Lobo Antunes says that, if by any chance, hypothetically, he wrote his autobiography, "I would not be publishing the autobiography of António Lobo Antunes, no, I would publish my notion of him, since that, what we are for ourselves, are no more than fantasies of what we are" since life "is a game of sincere phantoms" (ANTUNES 2012, p. 12).

It can be admitted, then, that in a book of fiction, an author reveals himself more than in a book of memoirs or a diary - as another $20^{\text {th }}$ Century Portuguese novelist, Vergílio Ferreira, suggested on one occasion. I believe so, yes, if we think that in a novel the plurality of voices makes it easier to express intimateness, of that which, in an autobiographical record, tends to be easier to be self-censured or concealed. Novels express moral imagination, multiplying life experiences and experiences lived.

And does historiography manage to give life to the personalities it portrays? I would say that with more difficulty, since, as we know, historians are concerned primarily with truth. And this has its limits. There are always zones which are obscure and not clarified in the lives of our ancestors. As the Catalan historian Jordi Canal observed in a recent lecture in Lisbon: historians tend to see people of the past in a more logical manner. Without the constraints of grounding and of truth, novelists can give free rein to imagination, can multiply lives - as a composer, at a concert, can multiply sounds. In this sense, the multiplicity of 436 viewpoints that we find in a great novel (including the narrator) can be seen as polyphony. And the ethical parameters themselves, and truth, are mobile. Where are good and evil in Dostoevsky's Crime and punishment? Or in the life of the student Rastignac, principal character of Le pére Goriot, by Balzac? This is an exercise, which evidently, is forbidden to the professional historian of our age.

Now, with the so called linguistic turn, the boundaries between history and literature have become blurred, which has led to a very fruitful discussion. The vogue of structuralism led to a rapprochement between history and linguistics - as other approximations have been verified between other human sciences. An example of this is the work of Régine Robin (ROBIN 1973). It was admitted that all "historical reality" was mediatized by discourse. Moreover, that history is reduced to the discursive dimension. Rolland Barthes even claimed that "the historical discourse is essentially ideological elaboration or, to be more precise, imaginary" (BARTHES 1987, p. 128). Only the discourses seemed to interest in their immanence, in their autonomy. The authors became devaluated (FOUCAULT 1970). A century after the peak of the scientific vogue, the historic discourse returned, moving closer - now in new terms - to the discourses of literature. The works of Hayden White (WHITE 1992) and of Paul Veyne (VEYNE 1983) contributed decisively to both. White valued the linguistic strategies in structuring and legitimating of the different interpretations of history. While it is true he denied history a scientific stature, it must not be forgotten that he was well aware of the distinction between history and novel (WHITE 1992, p. 17). On the other hand, Paul Veyne stated that history is "real novel" and also 
denied it the stature of science. And at the end of the decade of 1970, in which so many things changed in the life of humanity, Lawrence Stone tried to explain the revaluation of the narrative dimension of history, starting from the influence of anthropology, of intellectual history and to the interest for mental structures, without forgetting the intention of rendering historiography more accessible to the public (STONE 1986). In all these reflections, the nature of the writing of history and the statute of the discipline, were involved.

Some went much further, questioning the very "historical reality": everything in history tended to reduce itself to representations - re-representations of absences. The reality seemed to cease to exist out of the language. It was forgotten that representations are not produced out of their contexts and that the knowledge of these contexts and of their authors is relevant. How to understand, for instance, the complex phenomena of European immigration to the Americas, without taking into account the demographic, economic and social problems of the original societies, the motives and expectations of a better future of the immigrants, the characteristics of the destination societies and of their needs among other issues? Or how to understand the practice of slavery in the Atlantic space of modern times if we only kept to the plane of discourse - more so, since most of them limit themselves to the testimonies of the slave owners?

The reaction to the linguistic turn was immediate. Its critical balance has already begun (NOIRIEL 2005, p. 154-176; SPIEGEL 2009; DELACROIX 2011). I will not go back to it. But it is important to notice that recently, several historians have underlined the irreducible differences between the genders - history and literature - taking into account the fundamentals of the former in scientific research (NORA 2011, p. 7). In another angle of approach, some notice the uncertainties of the boundaries and the different alliances that these diverse genders establish with their readers. Without forgetting how much history can contribute to literary imagination and, on the other hand, how much the latter can make historians perceive the dimension of contingency and chance (OZOUF 2011, p. 18-24).

History helps to understand the human problems of the past - and even those of the present. But must not concern itself with judging men. What least matters is the judgment of values and adjectivation, in which some historians are so fertile. Those exercises, among many others, of course, are not forbidden to the fictionist or the memoirist. All history is narrative. Does this mean that it can be limited to a narrative dimension? By no means. There will always be multiple historiographies. But it will always be desirable to have a reflective and problematizing history that tears new horizons of understanding of human experience.

\section{Bibliographical References}

BARTHES, Rolland. O efeito de real. In: O rumor da língua. Lisboa: Edições 70, 1987 [1968], p. 131-136.

BELO, Ruy. Outono. In: Homem de palavras. Obra poética. Lisboa: Presença, 1980. 
BUÑUEL, Luis. O meu último suspiro. Lisboa: Distri Editora, 1983.

CARVALHO, Rómulo de. Memórias. Lisboa: FCG, 2010.

CATROGA, Fernando. Os passos do homem como restolho do tempo: memória e fim do fim da história. 2a edição. Coimbra: Almedina, 2011.

CERTEAU, Michel de. L'écriture de I’histoire. Paris: Gallimard, 1975.

CHARTIER, Roger. Au bord de la falaise: I'histoire entre certitudes et inquiétude. Paris: Albin Michel, 2009.

DELACROIX, C. Linguistic turn. In: DELACROIX, C. et al. (dir.). Historiographies

I: concepts et débats. Paris: Gallimard, 2010. p. 476-490.

FOUCAULT, Michel. L' ordre du discours. Paris: Gallimard, 1971.

GIL, José. Portugal, hoje: o medo de existir. 5a edição. Lisboa: Relógio de Água, 2005.

GODINHO, Vitorino Magalhães. Da dificuldade de pensar o nosso tempo. In: . Estudos e ensaios. V. I. Lisboa: João Sá da Costa, 2009, p. 25-76.

HARTOG, François. Regimes d'historicité: présentisme et experiences du temps. Paris: Seuil, 2003.

Croire en I'histoire. Paris: Flammarion, 2013.

HERCULANO, Alexandre. Moral. Velhice. O Panorama, v. 4, p. 243-244, 1840. . Cartas sobre a História de Portugal. In: Opúsculos IV. Lisboa: Ed. Presença, 1985 [1842], p. 189-239.

HOBSBAWM, Eric; RANGER, Terence (eds.). The Invention of Tradition. Cambridge: Cambridge University Press, 1983.

JASPERS, Karl. La situation spirituelle de notre époque. Paris-Louvaina: D. De Brouwer/E. Nauwelaerts, 1953.

KOSELLECK, Reinhart. Le futur passé: contribution à la sémantique des temps historiques. Paris: EHESS, 1990.

JUDT, Tony. $\mathbf{O}$ século $\mathbf{X X}$ esquecido: lugares e memórias. Lisboa: Edições 70, 2009.

Pós-Guerra: história da Europa desde 1945. Lisboa: Presença, 2010 [2005].

LACAPRA, Dominick. Historia y memoria después de Auschwitz. Buenos Aires: Prometeo, 2008.

LE GOFF, Jacques. História. In: Enciclopédia Einaudi. V. I: MemóriaHistória. Lisboa: INCM, 1984.

LUHMANN, Niklas. A improbabilidade da comunicação. Lisboa: Vega, 1999. 
MACAULAY. The Task of the Modern Historian. Disponível em: http://www. blupete.com/Literature/Essays/Best/MacaulayModHis. Access in: Dez. 4 2013.

MICHELET, Jules. Histoire de France: le Moyen Âge. Apresentação de Claude Mettra. Paris: R. Laffont, 1981 [1869].

NOIRIEL, Gérard. Sur la "crise" de I’histoire. Paris: Gallimard, 2005.

NORA, Pierre. Mémoire collective. In: LE GOFF, Jacques; CHARTIER, Roger; REVEL, Jacques (dir.). La Nouvelle Histoire. Paris: CEPL, 1978, p. 298401.

. Entre mémoire et histoire. La problématique des lieux. In: Les lieux de la mémoire. V. I. Paris: Gallimard, 1984, p. XVII-XLII.

. Histoire et roman: où passent les frontiers? Le Débat, n. 165, p. 6-12, 2011.

OZOUF, Mona. Récit des romanciers, récit des historiens. Le Débat, n. 165, p. 13-25, 2011.

PESSOA, Fernando. O caso mental português [1932]. In: SENA, Jorge de (ed.). Páginas de doutrina e estética. $2^{a}$ edição. Lisboa: Editorial Inquérito, [1946], p. 143-153.

POMIAN, K. Sobre la historia. Madrid: Cátedra, 2007.

RICOEUR, Paul. La mémoire, I’hstoire, l'oubli. Paris: Seuil, 2000.

ROBIN, Régine. Histoire et Linguistique. Paris: Armand Colin, 1973.

SANFELIPPO, Luis El trauma en la historia. Razones y problemas de una importación conceptual. Pasajes. Valencia, n. 40, p. 24-37, 2012-2013.

SPIEGEL, Gabrielle M. The Task of the Historian. The American Historical Review, n. 114, p. 1-15, 2009.

STENDHAL. Le Rouge et le Noir. Paris: Gallimard, 1991 [1830].

STONE, Lawrence. El resurgimiento de la narrativa: reflexiones acerca de una nueva y vieja historia. In: El pasado y el presente. México: Fondo de Cultura Económica, 1986 [1979], p. 95-120.

TRAVERSO, Enzo. Le passé, modes d'emploi: histoire, mémoire, politique. Paris: La Fabrique Ed., 2005.

VEYNE, Paul. Como se escreve a história. Lisboa: Edições 70, 1983 [1971].

WHITE, Hayden. Metahistoria: la imaginación histórica en la Europa del siglo XIX. México: Fondo de Cultura Económica, 1992 [1973]. 